\title{
The Effect of Entrepreneurial Knowledge and Environmental Support on Student Entrepreneurial Intention
}

\author{
Miswanto Miswanto ${ }^{\bowtie}$, Shofia Suparti, dan Yanuar Rifqi Abdullah \\ STIE YKPN School of Business, Yogyakarta, Indonesia \\ e-mail: miswanto.ykpn@gmail.com
}

\begin{abstract}
This study aims to examine the effect of entrepreneurial knowledge and environmental support on student entrepreneurship intentions. This study is a causal associative research with a quantitative approach. The variables of this study are entrepreneurial knowledge and environmental support as independent variables, entrepreneurship intentions as the dependent variable. This study is a research with 105 student respondents. Data collection techniques use questionnaire. Data analysis method used is regression. The results of this study indicate that (1) Entrepreneurial knowledge has a positive effect on entrepreneurial intentions and (2) Environmental support has a positive effect on entrepreneurial intentions. Therefore, the findings are that the knowledge and support of the environment has a positive effect on student entrepreneurship intentions.
\end{abstract}

Keywords: entrepreneurial knowledge, environmental support, and entrepreneurial intentions

\begin{abstract}
Abstrak
Tujuan penelitian ini menguji pengaruh pengetahuan kewirausahaan dan dukungan lingkungan terhadap minat berwirausaha mahasiswa. Penelitian ini adalah penelitian asosiatif kausal yang menggunakan pendekatan kuantitatif. Variabel penelitian ini terdiri dari pengetahuan kewirausahaan dan dukungan lingkungan sebagai variabel bebas, minat berwirausaha sebagai variabel terikat. Data penelitian ini diperoleh melalui responden mahasiswa yang berjumlah 105 mahasiswa. Teknik pengumpulan datanya memakai kuesioner yang diberikan kepada responden. Metode analisis terhadap data tersebut menggunakan regresi. Hasil yang didapatkan dalam penelitian ini adalah (1) Pengetahuan kewirausahaan mempunyai pengaruh positif terhadap minat berwirausaha dan (2) Dukungan lingkungan mempunyai pengaruh positif terhadap minat berwirausaha. Oleh karena itu, temuan penelitian ini bahwa pengetahuan kewirausahaan dan dukungan linkungan berpengaruh positif terhadap minat berwirausaha pada mahasiswa.
\end{abstract}

Kata kunci: pengetahuan kewirausahaan, dukungan lingkungan, dan minat berwirausaha 


\section{INTRODUCTION}

Entrepreneurship is an attempt by someone to create their own jobs, either opening a business or creating something new to improve the economy for themselves and for others. Entrepreneurship requires a willingness to take risks with full calculation, so as to overcome obstacles to achieve the expected success. Growing the entrepreneurial spirit of students in higher education can be an alternative to reducing the unemployment rate. By having an entrepreneurial spirit, students are hoped to be able to create jobs or become entrepreneurs after graduating from college. As stated by Buchori (2011) that the more developed a country the more people are educated, and the more important is the importance of entrepreneurship. Entrepreneurship is one of the supporting factors that determine the economic ups and downs, because the field of entrepreneurship has an influence on the freedom of people to work, create, innovate and become independent people.

According to Putra (2012), there are 6 factors that influence entrepreneurial intentions including entrepreneurship knowledge, environmental support, selfesteem, opportunities, personality, and finally, income and confidence. However, this research is limited only to examining the intentions of entrepreneurship in students and choosing entrepreneurial knowledge and family environment as factors that influence student entrepreneurship intentions.

In order for students to have entrepreneurial knowledge, several universities create curricula that include entrepreneurship courses. Entrepreneurial knowledge is what someone knows or understands about entrepreneurship. In entrepreneurship courses, students are given entrepreneurial theories and entrepreneurial practices. In addition, universities also often hold entrepreneurial seminars. The goal is that students have an entrepreneurial mentality and encourage them to become real entrepreneurs after they graduate, so that the number of entrepreneurs in Indonesia increases and can reduce unemployment.

Family environment is the first environment in a person's life. The family environment consists of parents, relatives and other closest relatives. one of the family environment is that parents will influence their children in determining their future, for example in terms of job selection. Becoming an entrepreneur cannot be separated from the support of parents or family and friends around him. If family and friends give support to entrepreneurial intentions, someone will have entrepreneurial intentions. If family and friends' environment does not support someone to do entrepreneurship, their entrepreneurial intentions will be limited or no. Based on observations and research a few years ago, most parents wanted their children to become civil servants. Attitudes and desires of parents towards the work of their children affect other family members, both directly and indirectly. For example, parents who are entrepreneurs can cause their children's intentions to become entrepreneurs. Family and social environment that supports a person to become an entrepreneur will also increase the person's intention to become an entrepreneur. Refer to the background of the above problems, this study is entitled "The Effect of Entrepreneurial Knowledge and Environmental Support on Student Entrepreneurial Intentions."

Refer to the background of the problem, the authors formulate the problem as follows: 1) whether entrepreneurial knowledge affects positively on student entrepreneurial intentions, and 2) whether environmental support affects positively on entrepreneurial intentions. Based on the problems outlined, the objective of this study is to test the effect of entrepreneurial knowledge and environmental support on intensions of student entrepreneurial. 
The results of this study are expected to provide the following benefits. First, the results of this study can add insight and enrich knowledge, especially in the field of entrepreneurship and become a reference for other researchers to conduct research on factors that influence entrepreneurial intentions. Second, this research can provide information to universities in an effort to increase entrepreneurial intentions for students.

With reference to the title of the study as mentioned above, the literature review presented below relates to the factors mentioned in the title. These factors are entrepreneurship intention, entrepreneurial knowledge and environmental support on students. Entrepreneurship intention is the factor that is affected. Entrepreneurial knowledge and environmental support on students are factors that are used as influencing factors.

Entrepreneurial intention is a sense of interest to become an entrepreneur who is willing to work hard and diligently to attain business progress. The intention of entrepreneurship is not carried from birth but grows and develops according to the influencing factors. Factors that influence the growth of deciding to become entrepreneurs are the proceeds of interaction of several factors, including the character of a person's personality and environment (Wahyono, 2014).

Intention is a feeling of prefer ability and a sense of attachment to a thing or activity, without anyone asking. Intention is principally the receipt of a relationship between oneself and an outside self. Slameto (2010) states that intention is a feeling of preference and a sense of interest in a thing or activity, in the absence of anyone asking. While Djamarah (2008) defines intentions as a settled tendency to care and remember some activities. Someone who has the intention to activity will care to the activity consistently with pleasure.

Entrepreneurial intention in a person can be lviewed from two key indicators, firstly how strong a person's attempts are to challenge to try entrepreneurial activities, and secondly how much effort someone plans to carry out entrepreneurial activities (Nasution, 2007). Suryana (2013) defines an entrepreneur as someone who has new business creativity, dares to bear risks and uncertainties that aim to make a profit.

According to Kasmir (2006), entrepreneurs are people who are dared in taking risks to start businesses in various opportunities. Factors that drive entrepreneurship intentions are personal, environmental, and sociological factors. Personal factors concerning aspects of personality include: 1) The existence of dissatisfaction with one's work, 2) The existence of termination of employment, no other work, 3) Impulse due to age, 4) Courage of risk, and 5) Commitment and high intention in business (Buchari, 2011).

Environmental factors related to the relationship with the physical environment include: 1) The existence of competition in the living world, 2) The existence of resources that can be utilized such as capital, savings, inheritance, buildings, and strategic locations, 3) Following business training courses or business incubators, and 4) Government policies, such as ease of business location, credit facilities and business guidance. Sociological factors related to relationships with family and so on, for example, are the presence of: 1) relationships or relationships for others and the existence of teams that can be invited to work together in business, 2) encouragement from parents to open businesses, 3) family assistance in various convenience, and 4) previous business experience (Hisrich, Peters, and Shepherd, 2010). 
Zimmerer, et al (2009) state that one of the driving factors to the entrepreneurship growth in a country lies in the role of universities by way of the practice of entrepreneurship education. According to Hidayatullah (2012), the factors that influence entrepreneurial intentions are intrinsic and extrinsic factors. Intrinsic factors are factors that arise due to the influence of stimulation from within the individual. Intrinsic factors as an incentive for entrepreneurship include the need for income, motives, self-esteem, feelings of pleasure and attention. Extrinsic factors are factors that affect an individual due to the impact of external stimuli. Extrinsic factors that influence entrepreneurial intentions accommodate family environment, community environment, chance and education (Efendi et al., 2018).

In studying this entrepreneurship intention, entrepreneurial knowledge is the factor chosen to be the factor that affects it. Supporting literature reviews are as follows. The most important activity involves the brain, including in the cognitive field. in cognitive culture, there are six levels of thought processes, the six levels are knowledge, understanding, application, analysis, synthesis, and assessment. In this research, the level to be discussed is knowledge. Knowledge is one's capability to recall events that have already been experienced, without expecting the ability to use them (Sudjono, 2009). According to Winkel (2004) that knowledge accommodate memories of things or events that have happened, studied, stored in memory and dug up when demanded.

Until now, the concept of entrepreneurship is still developing and constantly being developed. Entrepreneurship rises when an individual is brave to develop new businesses and ideas. According to Daryanto (2012) entrepreneurship is the capability to build something new and different through creative thinking and innovative action to build opportunities. Meanwhile, according to Hendro (2011) entrepreneurship is the ability to manage something that already exists in a person to be used and improved so that it will be useful in the future. According to Soegoto (2009: 3 ) entrepreneurship is one of the creative businesses that is built on innovation to produce something new, have added value, provide benefits, create jobs and the results are useful for others. Meanwhile, according to Suryana (2013) entrepreneurship is a creative and innovative capability that is made as a basis, tips, and resources to get opportunities for success. From some of the above opinions it can be concluded that entrepreneurship is one of the creative endeavors built on innovation to create opportunities and be set to good use so that it will gain greater profits and the results will be useful for others.

Entrepreneurial knowledge is one's ability to get something new past creative thinking and innovative action, so that it can create ideas or opportunities and can be put to good use. Entrepreneurial knowledge can be obtained through entrepreneurship education. Entrepreneurship materials can be delivered in accordance with the existing curriculum. The curriculum includes entrepreneurship education that studies one's values, abilities and behavior in creating and innovating (Rusdiana, 2014).

In addition, the quality of theoretical lessons to increase entrepreneurial knowledge or by direct practice of business spaciousness. Entrepreneurial knowledge gained by a person from the learning process through learning materials and from other sources is hoped to provide an overview and provision of entrepreneurship that can later be used as a material for one's consideration to determine the future and is expected to encourage someone to have an entrepreneurial intention.

The following is the literature used to explain environmental support on students. According to Hulukati (2015), the family 
environment is the first and foremost medium that influences children's developmental behavior. The family environment is the smallest group in the community be composed of fathers, mothers, children, brother, sister and other family members. Furthermore, in the family environment, especially parents, play a significant role in the development and growth of children. Parents also play a role as directors and mentors for the future. Indirectly parents can also influence the intentions of their children to choose work, and moreover to choose to become an entrepreneur (Bamford and Bruton, 2011).

According to Buchari (2011: 8), there is an influence from parents whose own business has a tendency for their children to become entrepreneurs as well. Children who have parents who are entrepreneurs or live in an entrepreneurial family environment will receive initial knowledge so as to form attitudes and perceptions about belief in entrepreneurial abilities. According to Sit (2012), the environment is the overall physical, natural, and social phenomena that are affected or influenced by the personal development and behavior of individuals in the environment.

Based on these descriptions it can be concluded that the family environment is the smallest group in society and is the first environment that influences the development and behavior of children. In the family environment, children get attention, affection, encouragement, guidance and example by parents to be able to develop their potential for future development. Family and social environment has a huge influence on the development and selection of a child's work. The influence of parents and social environment can occur through the way or model of parents and the environment in interacting.

In this study, the authors make hypotheses. The hypothesis is used as a temporary answer that must be tested based on the research method used in this study. Putra (2012) states that the factors used as measures that influence entrepreneurial intentions are personal, sociological and environmental. Suhartini (2011) states that the factors influencing student entrepreneurship intentions are income, feelings of pleasure, family environment, and education. Astiti (2014) states that Entrepreneurship Education influences entrepreneurial motivation and entrepreneurial skills of Economics Education students at Yogyakarta State University. In her research, Aprilianty (2012) finds that the potential of entrepreneurial personality, entrepreneurial knowledge, and the environment have impact on the entrepreneurial intentions of SMK Students in Agriculture in the Special Region of Yogyakarta.

Based on these studies, the framework of thinking is obtained that first that entrepreneurial knowledge is the ability of a person to produce something new over creative thinking and innovative action, so that the person can create ideas, opportunities and can be put to good use then they will get greater profits. Entrepreneurial knowledge is obtained by students from the learning process through learning materials and from other sources. The learning process is hoped to provide an overview and provision of entrepreneurship which can later be used as consideration by students to determine what business in the future. Second, the selection of occupational professions cannot be separated from the role of the family. The family is where the main activities of one's life take place. The family becomes a determinant in one's development. In the family, parents will direct their children to their future lives. Indirectly, parents can influence their children in choosing work. The work of parents, family environment, and also the social environment can be a trigger for entrepreneurial intentions in children. For example, parents who have businesses in certain fields will encourage 
their children to establish similar businesses. The role of the family is also very important in fostering entrepreneurial intentions for students. Entrepreneurship education can take place from an early age in the family environment.

Supporting the environment is a family environment which is where the main activities of one's life take place, so that the family becomes a determinant in one's development. The indicators used are parental support, and parental work (Buchari, 2011: 8). Support environment can also be from social environment (Purnonomi, 2015). According to Bukhori (2011) and Purnonomo (2015), environmental support has a positive influence on entrepreneurial intentions. Based on the description of the theory, frame of mind and some of the research results described above, the formulation of the research hypothesis is as follows:

H1: Entrepreneurial Knowledge has a positive effect on student entrepreneurial intentions.

H2: Environmental Support has a positive effect on student entrepreneurial intentions.

\section{METHOD}

This research was conducted at STIE YKPN Yogyakarta where the STIE YKPN students were used as research samples .Where the research was conducted in August 2016. The sample selection method used was non probability sampling with using a purposive sampling technique. This type of research is a causal research with a quantitative approach. This study aims to examine the effect of independent variables on the dependent variable. The independent variable is entrepreneurial knowledge and environmental support and the dependent variable is student entrepreneurial intentions.

The operational definition of entrepreneurial intentions as the dependent variable is as follows. Entrepreneurial Intention is the intention that arises from within a person for entrepreneurship. The indicators used are students who have entrepreneurial intentions because they want to not depend on others, want to be able to help the social environment, and are happy if they become an entrepreneur (Winkel, 2004; Zimmerer, et al., 2009).

Referring to the $\mathrm{H} 1$ and $\mathrm{H} 2$, the research model is as follows:

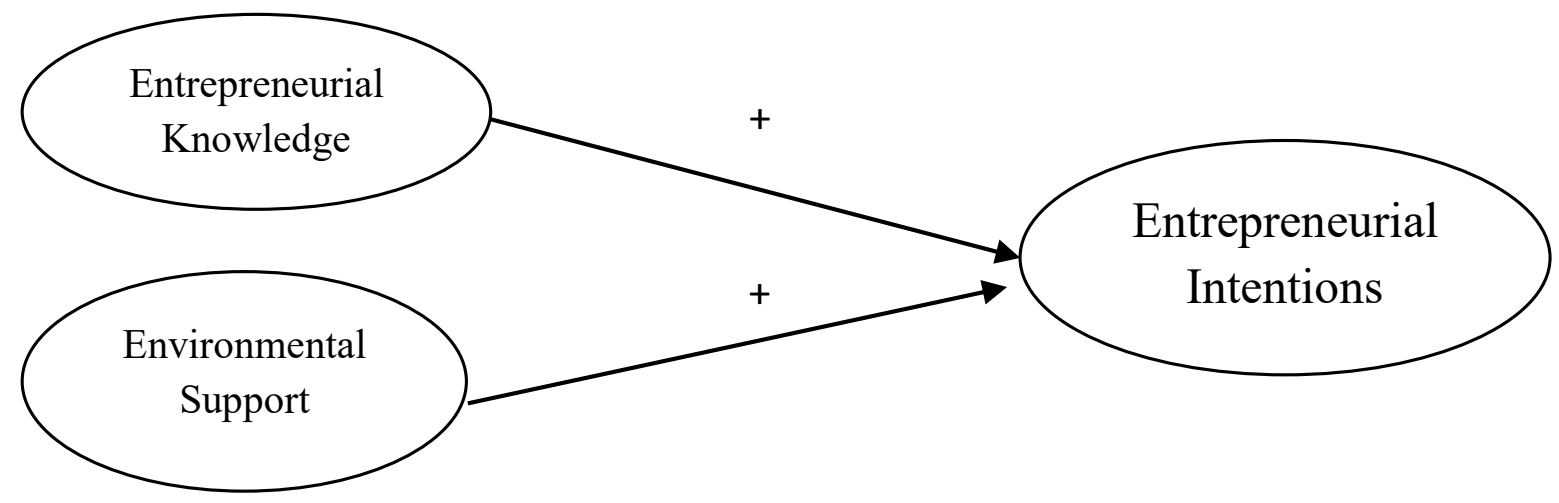

Figure 1. Research Model 
The operational definition of entrepreneurial knowledge and environmental support as independent variables are as follows. Entrepreneurial Knowledge is guidance given by someone to change a person's attitude and mindset so that he has the intention to become an entrepreneur. and the indicators used are adequate entrepreneurship education and attend entrepreneurship seminars (Zimmerer, et al., 2009). Supporting the environment is a family environment which is where the main activities of one's life take place, so that the family becomes a determinant in one's development. The indicators used are parental support, and parental work (Buchari, 2011: 8). Support environment can also be from friends around him (Purnonomo, 2015).

The data taken in this study are primary data. The method of data collection uses a research instrument (Widoyoko, 2012). The research instrument is a questionnaire sheet containing structured questions to be answered by respondents with a Likert scale used to measure variables. The Likert scale used in this study has dimensions 4 with a range of values from 1 to 4 . The score for the alternative answers to questions as follows. The score of strongly agree is 4 , the score of agree is 3 , the score of disagree is 2 , and the score of strongly disagree is 1 . Table 1 shows the indicat ors used in this research instrument.
The instrument used to measure variables was tested for validity and reliability. A valid and reliable instrument is a prerequisite for obtaining valid and reliable research results. A valid or valid instrument has high validity, whereas a less valid instrument means low validity. A questionnaire is told to be reliable if someone's answer to the question is consistent or stable from time to time (Ghozali, 2013).

Hypothesis testing can be done with simple and multiple regression. In this study, regression analysis used is simple regression based on causal relationships of one independent variable with one dependent variable (Sugiyono, 2012). This analysis is conducted to prove the hypothesis proposed, whether each independent variable influences the dependent variable. The equation of regression model is as follows:

$$
\mathrm{Y}=\mathrm{a}+\mathrm{bX}
$$

Note: $\mathrm{Y}=$ Subject in the predicted dependent variable; $\mathrm{a}=$ constant, which shows the value of $\mathrm{Y}$ when the value of $\mathrm{Y}$ $=0 ; \mathrm{b}=$ Number of direction or regression coefficient, if $(+)$ the direction of the line goes up, and if (-) the direction of the line goes down; dan $X=$ Subject of an independent variable that has a certain value.

After conducting the test, the next step is to analyze the model and determinant coefficient $\left(\mathrm{r}^{2}\right)$.

Table 1. Research Instruments

\begin{tabular}{|c|c|c|c|}
\hline No. & Variables & Indicator & Item Questions \\
\hline \multirow[t]{2}{*}{1.} & \multirow[t]{2}{*}{ Entrepreneurial Knowledge } & Adequate entrepreneurial knowledge & $1,3,5,6,7$ \\
\hline & & Following the entrepreneurial seminar & 2,4 \\
\hline \multirow[t]{3}{*}{2.} & \multirow[t]{3}{*}{ Environmental support } & Parental support & $8,9,10$ \\
\hline & & Family support & 11,12 \\
\hline & & Friends support & 13,14 \\
\hline \multirow[t]{2}{*}{3.} & \multirow{2}{*}{$\begin{array}{l}\text { Student entrepreneurial in- } \\
\text { tentions }\end{array}$} & Interested if becoming an entrepreneur & $15,19,20,21$ \\
\hline & & There is no dependence on others & $16,17,18$ \\
\hline
\end{tabular}




\section{RESULTS AND DISCUSSION}

The first data analysis is the analysis of the validity and reliability test. Respondents were students of STIE YKPN Yogyakarta and the number of those who filled out the questionnaire properly and correctly was 105 students. In this study, the validity value is sought by using the Pearson product moment correlation formula. Validity test is done by using the SPSS 23.0 for window program. If $r$ arithmetic $>r$ table then the statement in the questionnaire is considered valid or feasible to be used as data analysis. Table 2 shows that all question items used to measure all variables are valid.

Table 2. Validity Test Results for Variables of Entrepreneurial Knowledge

\begin{tabular}{ccc}
\hline Question & Total Correlation & Information \\
\hline 1 & 0,711 & valid \\
2 & 0.583 & valid \\
3 & 0.708 & valid \\
4 & 0.674 & valid \\
5 & 0.514 & valid \\
6 & 0.733 & valid \\
7 & 0.737 & valid \\
\hline
\end{tabular}

Source: processed primary data

Table 3. Test Results of Validity Test for Environmental Support Variables

\begin{tabular}{ccc}
\hline Question & Total Correlation & Information \\
\hline 1 & 0.867 & Valid \\
2 & 0.887 & Valid \\
3 & 0.818 & Valid \\
4 & 0.883 & Valid \\
5 & 0.904 & Valid \\
6 & 0.601 & Valid \\
7 & 0.344 & Valid \\
\hline
\end{tabular}

Source: processed primary data

Table 4. Test Results of Validity on Variables of Student Entrepreneurial Intentions

\begin{tabular}{ccc}
\hline Question & Total Correlation & Information \\
\hline 1 & 0.834 & valid \\
2 & 0.771 & valid \\
3 & 0,795 & valid \\
4 & 0.712 & valid \\
5 & 0,877 & valid \\
6 & 0.770 & valid \\
7 & 0.804 & valid
\end{tabular}

Source: processed primary data 
Reliability measurements are carried out using the Cronbach Alpha statistical test. A variable is said to be reliable if it gives a Cronbach Alpha value greater or equal to 0.60 (Ghozali, 2013). The result is that all variable measurement instruments are reliable. A summary of the reliability test results is presented in Table 5 .
The results of the analysis of the data above show that testing of hypotheses is feasible to be conducted as follows. .In this study, there are two independent variables that influence the independent variable. However, hypothesis testing conducted in this study does not use multiple linear regression but uses simple linear regression analysis.

Table 5. Reliability Test Results Instrument

\begin{tabular}{lcc}
\hline \multicolumn{1}{c}{ Variables } & Alfa value Chonbach & Information \\
\hline Knowledge Enterprise & 0,795 & reliable \\
Support Environment & 0.889 & reliable \\
Interest in Entrepreneurship & 0.901 & reliable \\
\hline
\end{tabular}

Source: processed primary data

After analysis of the validity and reliability test, the next, the authors conduct a descriptive data analysis and testing of classic assumptions..Descriptive data on all three variables has more than average values. The assumption test used is the normality and heteroscedasticity test Algifari (2016). The normality test uses the Kolmogrov Smirnov Test and the results indicate that the data used are normal. The heteroscedasticity test was performed using the Glejser Test and the results showed no heteroscedasticity. Multicollinerality test was not performed because the regression analysis used was simple linear regression. Based on these tests, the data used in this regression model fits the criteria of Best, Linear, Unlimited and Estimated (BLUE) Algifari (2016).
This study only emphasizes the t test to test the hypothesis. Partial regression test or $t$ test, basically shows how far the influence of one independent variable individually explains the variation of the dependent variable (Ghozali, 2013). Partial regression test is intended to determine whether the independent variable individually has an influence on the dependent variable, assuming the other variables are constant.

The first hypothesis (H1) states that entrepreneurial knowledge (X1) has a positive effect on entrepreneurial intentions (Y). The results obtained from the X1 regression analysis against $\mathrm{Y}$ are presented in the following table:

Table 6. Testing Results on H1

\begin{tabular}{lccccc}
\hline Variables & \multicolumn{2}{c}{ Regression Coefficients } & F count & Sig. & Adjusted $\mathbf{r}^{2}$ \\
& B & Std. Error & & & \\
\hline Constant & 1.545 & 0.305 & 31.694 & 0.00 & 0.235 \\
X1 & 0.603 & 0.107 & & 0.00 & \\
\hline
\end{tabular}

Source: Processed data 
The table above shows the probability value of F is $0 \%$, which means less significance level of $5 \%$. Therefore, the regression model can be used. In this table, the probability value $\mathrm{t}$ of $0 \%$ is less than $5 \%$. Therefore, the first hypothesis is supported, so it can be stated that entrepreneurial knowledge has a positive effect on entrepreneurial intentions. The constant value (a) is 1.545 and the value of the regression coefficient (b) is 0.603 , so the linear regression equation is as simple as follows:

$$
\mathrm{Y}=1.545+0.603 \mathrm{X} 1
$$

The regression equation above shows a constant of 1.545 . This value indicates that if the value of the independent variable $\mathrm{X} 1$ is 0 (zero), then the value of the dependent variable $(\mathrm{Y})$ is 1.545. The regression coefficient of variable $\mathrm{X} 1$ is 0.603 . This means if entrepreneurial knowledge (X1) increases by one point, the entrepreneurial intention (Y) will increase by 0.603 points. The coefficient of determination (adjusted $\mathrm{r}^{2}$ ) is 0.235 . This value means that $23.5 \%$ change in the entrepreneurial knowledge variable (X1) is influenced by the entrepreneurial intention variable $(\mathrm{Y})$, whilst the remaining $76.5 \%$ is influenced by other variables not examined in this study.

The following is $\mathrm{H} 2$ testing. The second hypothesis (H2) states that environmental support (X2) has a positive effect on entrepreneurial intentions (Y). The proceeds of $\mathrm{H} 2$ test are presented in Table 7 below.
The table above shows that the F test is significant because the probability value of $0 \%$ is smaller than the significance level of $5 \%$, so that the regression model can be used. Based on the t test, the regression coefficient has a significant positive effect because the probability value of $0 \%$ is lower than the 5\% significance level. Thus, environmental support has a positive influence on entrepreneurial intentions. The constant value (a) is 1.647 and the value of the regression coefficient (b) is 0.542 so the equation of simple linear regression is as follows:

$$
Y=1.647+0.542 X 2
$$

The regression equation above shows a constant of 1.647. This value indicates that if the value of the independent variable X2 is 0 (zero), then the value of the dependent variable (Y) is 1.647. The coefficient value of $\mathrm{X} 2$ is 0.542 . This value means that if environmental support (X2) increases by one point, the value of entrepreneurial intention (Y) will increase by 0.542 points The determinant coefficient (adjusted $r^{2}$ ) is presented at 0.374 . This value means that $37.4 \%$ of changes in the entrepreneurship intention variable (Y) are influenced by environmental support variables (X1), whilst the remaining $62.6 \%$ is influenced by other variables not examined in this study.

Discussion of the results of data analysis and testing of these hypotheses is as follows. In this study, the results indicate

Table 7. Testing Results on $\mathbf{H} 2$

\begin{tabular}{lccccc}
\hline Variables & \multicolumn{2}{c}{ Regression Coefficients } & F count & Sig. & Adjusted $\mathbf{r}^{2}$ \\
& B & Std. Error & & & \\
\hline Constant & 1.647 & 0.207 & 61.471 & 0.00 & 0.374 \\
X2 & 0.542 & 0.069 & & 0.00 & \\
\hline
\end{tabular}

Source: processed data 
that entrepreneurial knowledge has a positive influence on entrepreneurial intentions. This finding is in accordance with the findings of previous studies. Therefore, this finding can be used by university administrators to create a curriculum so that graduates have entrepreneurial intentions. The intention of entrepreneurship is important to be able to produce new entrepreneurs. For the government, especially the national education department, this finding can be proved that what has been done by the government is true, that is, the government asks every university to include entrepreneurship courses in its curriculum so that the graduates have a job creation profile, and not just job seekers. For students who want to become entrepreneurs, these findings provide input to students that entrepreneurial knowledge is really important to grow their intentions of entrepreneurship. Therefore, students who truly have an entrepreneurial intention should study as much as possible to obtain good and true entrepreneurial knowledge.

The results this study indicate environmental support has a positive influence on entrepreneurial intentions. This finding is in accordance with the findings of previous studies. Therefore, this finding can be used by university administrators and lecturers of entrepreneurship courses to create an academic environment around the campus that supports students with entrepreneurial intentions. Students' parents and the general public can take advantage of this research to provide direction so that their children and young people enter into relationships and environments that support the creation of entrepreneurial intentions. This research also provides direction to students who want to become entrepreneurs. Students should protect their social environment. Do not enter and be in a social environment that leads to being lazy and mentally job seekers. Students in looking for friends should look for friends or relationships who like business activities and have a mental job provider.

\section{CONCLUSION AND RECOMMENDA- TION}

This research was conducted using a sample of students studying at STIE YKPN Yogyakarta. Data collection methods in this study used a questionnaire. Based on the results of hypothesis testing, the conclusion of this study is that there is a positive influence of entrepreneurial knowledge and environmental support on student entrepreneurial intentions. In order for students to have entrepreneurial intentions, the curriculum offered by universities, institutes, and colleges must have courses that can enable students to have knowledge and skills about entrepreneurship. In addition, interested parties, such as universities or families, must be able to create an environment conducive to doing business or create an environment that can support students with entrepreneurial intentions. If students enter an environment that is not conducive to entrepreneurship, student entrepreneurship intentions will be difficult to realize.

Research limitations and suggestions in this study are as follows. The limitations of this study include the following. First, this research has not been able to reveal $100 \%$ of the variables that affect student entrepreneurship intentions. This study only examines the effect of entrepreneurial knowledge and environmental support on student entrepreneurship intentions. Secondly, this research was only conducted in the environment of students studying at STIE YKPN Yogyakarta. Third, despite using two independent variables, testing the hypothesis uses only a simple linear regression model. Fourth, the use of questionnaires in data collection is expected that respondents can provide answers that are in accordance with the actual conditions, but in reality it is difficult to control. Fifth, there is a limitation of research time, so there is a possibility that the sample collected is not maximally representative of the population. 
With regard to the limitations of this study, suggestions for future research are as follows. First, it is necessary to add independent variables, so that other factors that can influence entrepreneurial intentions can be identified. Second, for better research in subsequent studies that use more than one independent variable, the test uses multiple linear regression models. Third, increasing the number of samples by involving several universities in Yogyakarta or other cities, so that the generality of research results can be known. Fourth, there is a need for a better questionnaire so that respondents can understand better the contents of the questions, so that respondents' mistakes can be minimized.

\section{REFERENCES}

Algifari. 2016. Statistika Induktif untuk Ekonomi dan Bisnis. Edisi 3, Yogyakarta: Unit Penerbit dan Percetakan STIM YKPN.

Aprilianty, Eka. 2012. Pengaruh Kepribadian Wirausaha, Pengetahuan Kewirausahaan, dan Lingkungan terhadap Minta Berwirausaha Siswa SMK. Jurnal Pendidikan Vokasi, Vol. 2, Nomor 3.

Arikunto, Suharsimi. 2010. Prosedur Penelitian Suatu Pendekatan Praktek. Jakarta: PT Rineka Cipta.

Astiti, Yunita W. 2014. Pengaruh Pendidikan Kewirausahaan terhadap Motivasi Berwirausaha dan Keterampilan Mahasiswa Pendidikan Ekonomi Universitas Negeri Yogyakarta. Skripsi, Program Studi Pendidikan Ekonomi, Universitas Negeri Yogyakarta.

Bamford, C.E. and Bruton, G.D. 2011. Entrepreneurship: A Small Business Approach. International Edition, New York: McGraw-Hill.
Basrowi. 2011. Kewirausahaan untuk Perguruan Tinggi. Bogor: Ghalia Indonesia.

Daryanto. 2012. Pendidikan Kewirausahaan. Yogyakarta: Gava Media.

Dewi, Anita V. 2013. Pengaruh Pengalaman Pendidikan Kewirausahaan dan Keterampilan Kejuruan terhadap Motivasi Berwirausaha Siswa. Jurnal Pendidikan Vokasi, Vol. 3, No. 2.

Djamarah, Syaiful Bahri. 2008. Psikologi Belajar. Jakarta: Rineka Cipta.

Efendi, Y. E., Patriasih, R., dan Setiawati, T. 2018. Minat Instrinsik dan Ekstrinsik Wirausaha pada Siswa SMK Negeri 9 Bandung. Media Pendidikan, Gizi dan Kuliner. Vol. 7, No. 2.

Ghozali, Imam. 2013. Aplikasi Analisis Multivariate dengan Program IBM SPSS 21. Semarang: Badan Penerbit Universitas Diponegoro.

Hendro. 2011. Dasar-Dasar Kewirausahaan. Erlangga : Jakarta.

Hidayatullah, Nurchotim Lukman (2012). Minat Berwirausaha Program Studi S1 Pendidikan Teknik Elektro Jurusan Teknik Elektri Fakultas Teknik Universitas Negeri Semarang. Skripsi. Universitas Negeri Semarang.

Hisrich, R.D., Peters, M. P., and Shepherd, D.A. 2010. Entrepreneurship. Eight Edition, Singapore: McGraw-Hill.

Hulukati, Wenny. 2015. Peranan Lingkungan Keluarga terhadap Perkembangan Anak. Muswa, Vol. 7, No. 2: 265282.

Kasmir. 2006. Kewirausahaan. Jakarta: PT Rajagrafindp Persada.

Rusdiana, H.A. 2014. Kewirausahaan Teori dan Praktik. Bandung: CV Pustaka Setia. 
Nasution, Arman H. et al. 2007. Etrepreneurship Membangun Spirit Teknopreneurship. Yogyakarta: C.V Andi Offset.

Purnomo, Muhamad Tito. 2015. Pengaruh Pengetahuan Kewirausahaan dan Lingkugan Sosial terhadap Minat Wirausaha Siswa Teknik Kendaraan Ringan SMK Negeri Seyegan. Skripsi. Program Studi Pendidikan Teknik Otomotif Fakultas Teknik UNY.

Putra, R. A. 2012. Faktor-Faktor Penentu Minat Mahasiswa Manajemen untuk Berwirausaha (Studi Mahasiswa Manajemen FE Universitas Negeri Padang). Jurnal Hasil Riset. Jurnal Manajemen, Vol 01, No. 01.

Slameto. 2010. Belajar dan Faktor-Faktor yang Mempengaruhinya. Edisi revisi, P Rineka Cipta.

Sit, Masganti. 2012. Perkembangan Peserta Didik. Medan: Perdana Publishing.

Soegoto, Eddy S. 2009. Enterpreneurship Menjadi Pebisnis Ulung. Jakarta: PT.ELEX Media Komputindo.

Sudjono, Anas. 2009. Pengantar Evaluasi Pendidikan. Jakarta: Rajawali Pers

Sugiyono. 2012. Metode Penelitian Kuantitatif, Kualitatif, dan $R \& D$. Bandung: CV ALFABETA

Suhartini, Yati. 2011. Analisis FaktorFaktor yang Mempengaruhi Minat
Mahasiswa dalam Berwirausaha (Studi pada Mahasiswa Universitas PGRI Yogyakarta). AKMENIKA UPY. 9(10): 1-15.

Suryana, Yuyus. 2013. Kewirausahaan. Jakarta: Kencana.

Wahyono, Budi. 2014. Pengaruh Pendidikan Kewirausahaan terhadap Niat Berwirausaha Siswa SMK N 1 pada Tahun 2013. Tesis. Universitas Sebelas Maret Surakarta.

Wibowo, Agus. 2011. Pendidikan Kewirausahaan (Konsep dan Strategi). Yogyakarta: Pustaka Pelajar.

Widoyoko, Eko Putro. 2012. Teknik Penyusunan Instrumen Penelitian. Yogyakarta: Pustaka Pelajar.

Winarno. 2011. Pengembangan Sikap Entrepreneurship dan Intrapreneurship. Jakarta: PT Indeks.

Winkel. 2004. Psikologi Pengajaran. Yogyakarta: Media Aba.

Wiyono, Gendro. 2011. Merancang Penelitian Bisnis dengan Alat Analisis SPSS 17.0 \& Smart PLS 2.0. Yogyakarta: Unit Penerbit dan Percetakan STIM YKPN.

Zimmerer, Thomas W. et al., 2009. Kewirausahaan. $5^{\text {th }}$ Edition, Alih Bahasa oleh Kwary, D.A. Jakarta: Salemba Empat. 
